\title{
PENGARUH GAYA KEPEMIMPINAN, MOTIVASI GURU DAN LINGKUNGAN KERJA FISIK TERHADAP KINERJA GURU SMAN 1 TANGGUL JEMBER
}

\section{EFFECT OF LEADERSHIP STYLE, TEACHER MOTIVATION AND PHYSICAL WORK ENVIRONMENT ON TEACHER PERFORMANCE SMAN 1 TANGGUL JEMBER}

\author{
Bayu Hendro Priyono', Nurul Qomariah' ${ }^{2}$, Pawestri Winahyu ${ }^{3}$ \\ Fakultas Ekonomi Universitas Muhammadiyah Jember \\ Email : nurulqomariah@unmuhjember.ac.id, \\ pawestri@unmuhjember.ac.id
}

\begin{abstract}
ABSTRAK
Penelitian ini dilakukan pada guru SMAN 1 Tanggul Jember. Penelitian ini bertujuan untuk mengetahui pengaruh gaya kepemimpinan, motivasi guru dan lingkungan kerja fisik terhadap kinerja guru. Dalam penelitian ini data dikumpulkan dengan alat bantu berupa observasi, wawancara dan kuesioner terhadap 40 responden dengan teknik sensus, yang bertujuan untuk mengetahui persepsi responden terhadap masing-masing variabel. Analisis yang digunakan meliputi uji instrumen data (uji validitas, dan uji reliabilitas), analisis regresi linear berganda, uji asumsi klasik (uji normalitas, uji multikolinearitas, uji heteroskedastisitas), dan uji hipotesis (uji F,uji t, koefisien determinasi). Dari hasil analisis menggunakan regresi dapat diketahui bahwa variabel gaya kepemimpinan, motivasi guru dan lingkungan kerja fisik, semuanya berpengaruh positif terhadap kinerja guru. Dari uji t diperoleh hasil gaya kepemimpinan, motivasi guru dan lingkungan kerja fisik, semuanya berpengaruh signifikan terhadap kinerja guru.
\end{abstract}

Kata Kunci: gaya kepemimpinan, motivasi guru, lingkungan kerja fisik dan kinerja guru

\begin{abstract}
This research was conducted at teacher of SMAN 1 Tanggul Jember. This study aims to determine the effect of leadership style, teacher motivation and physical work environment on teacher performance. In this research the data collected by means of aids in the form of observation, interview and questionnaire to 40 respondents with census technique, which aims to know the perception of respondents to each variable. The analysis used included instrument test data (validity test, reliability test), multiple linear regression analysis, classical assumption test (normality test, multicollinearity test, heteroscedasticity test), and hypothesis test ( $\mathrm{F}$ test, $\mathrm{t}$ test, coefficient of determination). From the analysis using regression can be seen that the variables of leadership style, teacher motivation and physical work environment, all have a positive effect on teacher performance. From t-test, the result of leadership style, teacher's motivation and physical work environment all have a significant effect on teacher performance.
\end{abstract}

Keywords: leadership style, teacher motivation, physical work environment and teacher performance 


\section{PENDAHULUAN}

Manusia memiliki kemauan atau kebutuhan yang sifatnya berbeda-beda, tidak hanya berbeda dalam kemampuan melakukan sesuatu tetapi juga dalam kemauan atau motivasi mereka untuk melakukan sesuatu. Jika hal tersebut ditinjau dari sudut pandang manajemen, maka untuk memenuhi kebutuhan tersebut harus melalui hubungan dengan orang lain melalui pekerjaan dan tugas-tugas yang ada. Sekolah sebagai lembaga pendidikan formal berfungsi menyiapkan sumber daya manusia dan merupakan komponen penting dalam pembangunan di segala bidang.

Munib (2011) mendefinisikan bahwa pendidikan merupakan usaha sadar dan sistematis yang dilakukan oleh orang-orang yang diserahi tanggung jawab untuk mempengaruhi siswa agar mempunyai sifat dan tabiat sesuai dengan cita-cita pendidikan. Tujuan pendidikan nasional tersebut akan terwujud apabila semua pihak yang terkait turut berperan serta dalam meningkatkan mutu pendidikan bangsa. Pemerintah Indonesia sejak tahun 2013 merintis program pendidikan menengah universal atau pendidikan 12 tahun yang diharapkan tuntas pada tahun 2025 dan untuk mendukung program ini, pemerintah membutuhkan anggaran Rp 25 triliun agar program wajib belajar ini bisa dilaksanakan secara gratis (Ikrom., dkk, 2015). Semua pihak berperan serta dan saling berkoordinasi maka akan tercipta siswa yang berkualitas. Namun untuk menciptakan peserta didik yang berkualitas banyak faktor yang mempengaruhi, salah satunya yaitu kinerja guru.

Kinerja guru dalam pembelajaran merupakan faktor utama dalam pencapaian tujuan pendidikan, karena guru merupakan ujung tombak dalam dunia pendidikan. Pembelajaran yang berkualitas merupakan cerminan dari kinerja guru tersebut. Dengan kata lain semakin baik kinerja guru maka semakin baik juga pembelajaran di dalam kelas. Rusman (2012) menyatakan bahwa pembelajaran adalah proses interaksi siswa dengan guru dan sumber belajar pada suatu lingkungan belajar. Pembelajaran haruslah berpusat pada siswa karena subyek pembelajaran adalah siswa (Suprijono 2009). Kepemimpinan seorang pemimpin (kepala sekolah) akan mampu membedakan antara suatu organisasi dengan organisasi lainnya. Gaya kepemimpinan yang dimiliki oleh pemimpin (kepala sekolah) dalam memimpin suatu organisasi akan mempengaruhi kinerja daripada guru itu.

Peningkatan terhadap kinerja guru di sekolah perlu di lakukan baik oleh guru sendiri yaitu melalui motivasi yang di milikinya maupun dari kepala sekolah melalui 
kepemimpinan dan pembinaannya. Semua orang adalah pemimpin, meski orang itu tidak mempunyai kedudukan resmi sebagai pemimpin (Azhad dkk., 2015). Gaya kepemimpinan merupakan norma perilaku yang dipergunakan oleh seseorang pada saat orang tersebut mencoba mempengaruhi perilaku orang lain. Gaya kepemimpinan banyak mempengaruhi keberhasilan seorang pemimpin dalam mempengaruhi perilaku bawahannya. Kepemimpinan suatu organisasi perlu mengembangkan staf dan membangun iklim motivasi yang menghasilkan tingkat produktivitas yang tinggi. Cara pendekatan kepala sekolah terhadap bawahannya dalam hal ini guru merupakan kunci dari kinerja seorang guru. Berdasarkan interview terhadap beberapa guru, kepala sekolah pada periode 1 dan 2 cenderung menggunakan gaya kepemimpinan represif yang mengakibatkan beberapa guru "malas" untuk sekedar masuk untuk mengajar. Untuk periode 3 atau sekarang kepala sekolah lebih bersifat terbuka dan mengajak bersamasama untuk mencapai tujuan bersama yaitu memajukan siswa.

Jumlah guru yang tidak masuk kerja mengindikasikan motivasi kerja yang dipengaruhi oleh banyak faktor. Menurut Herman (2008), semakin baik baik presensi kehadiran seorang karyawan mempengaruhi kinerja guru tersebut. Hal itu dikarenakan karyawan yang tidak pernah absen selalu dapat memnuhi target yang dibebankan kepadanya karena adanya kebiasaaan yang terus menerus atau berkelanjutan mengenai pemenuhan target. Absensi karyawan tersebut secara tidak langsung berpengaruh juga terhadap penurunan kinerja guru SMAN 1 Tanggul dapat dilihat pada Tabel di bawah ini.

Tabel 1. Penilaian Kinerja Guru (PKG) Per 16 Desember 2016

\begin{tabular}{ccccc}
\hline No & Identitas & Target & Pencapaian & Keterangan \\
\hline $\mathbf{1}$ & EP & 78,00 & 92.86 & Tercapai \\
\hline $\mathbf{2}$ & SMRA & 78,00 & 87.5 & Tercapai \\
\hline $\mathbf{3}$ & HP & 78,00 & 87.5 & Tercapai \\
\hline $\mathbf{4}$ & As & 78,00 & 83.93 & Tercapai \\
\hline $\mathbf{5}$ & Ks & 78,00 & 87.5 & Tercapai \\
\hline $\mathbf{6}$ & RP & 78,00 & 89.29 & Tercapai \\
\hline $\mathbf{7}$ & IS & 78,00 & 89.29 & Tercapai \\
\hline $\mathbf{8}$ & WMI & 78,00 & 83.93 & Tercapai \\
\hline $\mathbf{9}$ & TS & 78,00 & 85.71 & Tercapai \\
\hline $\mathbf{1 0}$ & MD & 78,00 & 83.93 & Tercapai \\
\hline $\mathbf{1 1}$ & WN & 78,00 & 89.29 & Tercapai \\
\hline $\mathbf{1 2}$ & WS & 78,00 & 87.5 & Tercapai \\
\hline $\mathbf{1 3}$ & Bd & 78,00 & 85.71 & Tercapai \\
\hline $\mathbf{1 4}$ & BS & 78,00 & 85.71 & Tercapai \\
\hline
\end{tabular}




\begin{tabular}{lcccc}
\hline $\mathbf{1 5}$ & RW & 78,00 & 85.71 & Tercapai \\
\hline $\mathbf{1 6}$ & DH & 78,00 & 83.93 & Tercapai \\
\hline $\mathbf{1 7}$ & WYA & 78,00 & 83.93 & Tercapai \\
\hline $\mathbf{1 8}$ & SA & 78,00 & 85.71 & Tercapai \\
\hline $\mathbf{1 9}$ & MT & 78,00 & 89.29 & Tercapai \\
\hline $\mathbf{2 0}$ & IRR & 78,00 & 89.29 & Tercapai \\
\hline $\mathbf{2 1}$ & EH & 78,00 & 85.71 & Tercapai \\
\hline $\mathbf{2 2}$ & ELK & 78,00 & 80.36 & Tercapai \\
\hline $\mathbf{2 3}$ & YWK & 78,00 & 83.93 & Tercapai \\
\hline $\mathbf{2 4}$ & MPU & 78,00 & 80.36 & Tercapai \\
\hline $\mathbf{2 5}$ & BSW & 78,00 & 83.93 & Tercapai \\
\hline $\mathbf{2 6}$ & FW & 78,00 & 82.14 & Tercapai \\
\hline $\mathbf{2 7}$ & DPM & 78,00 & 83.93 & Tercapai \\
\hline $\mathbf{2 8}$ & YW & 78,00 & 83.93 & Tercapai \\
\hline $\mathbf{2 9}$ & EH & 78,00 & 78.57 & Tercapai \\
\hline $\mathbf{3 0}$ & RNF & 78,00 & 76.79 & Tercapai \\
\hline $\mathbf{3 1}$ & MHE & 78,00 & 78.57 & Tercapai \\
\hline $\mathbf{3 2}$ & DSU & 78,00 & 80.36 & Tercapai \\
\hline $\mathbf{3 3}$ & EAI & 78,00 & 78.57 & Tercapai \\
\hline $\mathbf{3 4}$ & RNRP & 78,00 & 78.57 & Tercapai \\
\hline $\mathbf{3 5}$ & RM & 78,00 & 78.57 & Tercapai \\
\hline $\mathbf{3 6}$ & IRSR & 78,00 & 78.57 & Tercapai \\
\hline $\mathbf{3 7}$ & MRA & 78,00 & 78.57 & Tercapai \\
\hline $\mathbf{3 8}$ & Sh & 78,00 & 89.71 & Tercapai \\
\hline $\mathbf{3 9}$ & TTS & 78,00 & 83.82 & Tercapai \\
\hline $\mathbf{4 0}$ & St & 78,00 & 89.71 & Tercapai \\
\hline Sumb & NA Tangur & & \\
\hline
\end{tabular}

Sumber: SMAN 1 Tanggul, 2017

Dari uraian yang sudah disampaikan maka rumusan masalah dalam penelitian ini adalah :

1. Apakah gaya kepemimpinan persuasif berpengaruh signifikan terhadap kinerja guru SMAN 1 Tanggul?

2. Apakah motivasi kerja berpengaruh signifikan terhadap kinerja guru SMAN 1 Tanggul?

3. Apakah lingkungan kerja fisik berpengaruh signifikan terhadap kinerja guru SMAN 1 Tanggul?

\section{TINJAUAN PUSTAKA}

\section{Manajemen Sumber Daya Manusia}

Manusia merupakan salah satu faktor produksi yang perlu mendapatkan perhatian yang khusus dari perusahaan, karena manusia sebagai penggerak aktivitas perusahaan, maka manajemen sumber daya manusia memfokuskan perhatiannya kepada masalah- 
masalah kepegawaian. Hasibuan (2013) mendefinisikan manajemen sumber daya manusia adalah ilmu dan seni yang mengatur hubungan dan peranan tenaga kerja agar efektif dan efisien membantu terwujudnya tujuan perusahaan, karyawan dan masyarakat. Sedangkan menurut Mangkunegara (2013) mengatakan bahwa manajemen sumber daya manusia merupakan suatu perencanaan, pengorganisasian, pengkoordinasian, pelaksanaan, dan pengawasan terhadap pengadaan, pengembangan, pemberian balas jasa, pengintegrasian, pemeliharaan, dan pemisahan tenaga kerja dalam rangka mencapai tujuan organisasi.

\section{Perilaku Organisasi}

Perilaku organisasi adalah suatu ilmu perilaku terapan dibangun di atas kontribusi dari sejumlah disiplin ilmu perilaku, terutama psikologi dan psikologi sosial, sosiologi, dan antropologi. Kontribusi psikologi terutama pada tingkat individu atau mikro analisis, sedangkan disiplin lain telah berkontribusi untuk pemahaman kita tentang konsep makro seperti proses kelompok dan organisasi. Model berikut adalah gambaran dari kontribusi besar untuk mempelajari perilaku organisasi (Robbins dan Judge, 2013).

\section{Kinerja}

Kinerja merupakan gambaran mengenai tingkat pencapaian pelaksanaan suatu program kegiatan atau kebijakan dalam mewujudkan sasaran, tujuan, visi dan misi organisasi yang dituangkan melalui perencanaan strategis suatu organisasi. Kinerja dapat diukur apabila individu telah mempunyai kriteria atau standar keberhasilan tolok ukur yang ditetapkan oleh organisasi. Oleh karena itu, jika tanpa tujuan dan target yang ditetapkan dalam pengukuran, maka kinerja pada seseorang atau organisasi tidak mungkin dapat diketahui bila tidak ada tolok ukur keberhasilnya (Moeheriono, 2012). Kinerja perlu dijdikan sebagai bahan evaluasi bagi pemimpin atau manajer. Nawawi (2011) mengatakan bahwa kinerja adalah (a) sesuatu yang dicapai, (b) prestasi yang diperlihatkan, (c) kemampuan kerja. Kinerja perlu dijdikan sebagai bahan evaluasi bagi pemimpin atau manajer. Nawawi (2011) mengatakan bahwa kinerja adalah (a) sesuatu yang dicapai, (b) prestasi yang diperlihatkan, (c) kemampuan kerja. Menurut Usman (2009) penilaian adalah penentuan derajad kualitas berdasarkan indikator yang ditetapkan terhadap penyelenggaraan pekerjaan. Kinerja ialah hasil kerja dan kemajuan yang telah dicapai seorang dalam bidang tugasnya. Kinerja selalu merupakan tanda keberhasilan suatu organisasi dan orang-orang yang ada di dalam organisasi tersebut. Menurut Supardi (2014) kinerja sangat dipengaruhi oleh karakteristik individu yang 
terdiri atas pengetahuan, keterampilan, kemampuan, motivasi, kepercayaan, nilai-nilai serta sikap. Kinerja guru menurut Mangkuprawira dan Vitalaya dalam Yamin dan Maisah (2010) dipengaruhi oleh beberapa faktor yang terdiri atas faktor intrinsik guru (personal) dan ekstrinsik, yaitu kepemimpinan, sistem, tim, dan situasional. Uraian rincian faktor-faktor tersebut adalah sebagai berikut:

a. Faktor personal, meliputi unsur pengetahuan, keterampilan, kemampuan, kepercayaan diri, motivasi dan komitmen yang dimiliki oleh tiap individu guru.

b. Faktor kepemimpinan, meliputi aspek kualitas manajer dan team leader dalam memberikan dorongan, semangat, arahan, dan dukungan kerja pada guru.

c. Faktor tim, meliputi kualitas dukungan dan semangat yang diberikan oleh rekan dalam satu tim, kepercayaan terhadap sesama anggota tim, kekompakan, dan keeratan anggota tim.

d. Faktor sistem, meliputi sistem kerja, fasilitas yang diberikan oleh pimpinan sekolah, proses organisasi sekolah dan kultur kerja dalam organisasi sekolah.

e. Faktor situasional, meliputi tekanan dan perubahan lingkungan eksternal dan internal.

\section{Gaya Kepemimpinan}

Untuk memahami gaya kepemimpinan terlebih dahulu kita ketahui definisi kepemimpinan menurut para ahli. Menurut House dalam Yukl (2009) mengatakan bahwa: Kepemimpinan adalah kemampuan individu untuk mempengaruhi, memotivasi, dan membuat orang lain mampu memberikan kontribusinya demi efektivitas dan keberhasilan organisasi. Jadi dari pendapat House dapat dikatakan bahwa kepemimpinan merupakan cara mempengaruhi dan memotivasi orang lain agar orang tersebut mau berkontribusi untuk keberhasilan organisasi. Kepemimpinan dalam organisasi diarahkan untuk mempengaruhi orang-orang yang dipimpinnya, agar mau berbuat seperti yang diharapkan ataupun diarahkan oleh orang lain yang memimpinnya (Sutikno, 2014).

\section{Motivasi Kerja}

Mc Clelland mengatakan bahwa kekuasaan (power), afiliasi (affiliation) dan prestasi (achievement) adalah motivasi yang kuat pada setiap individu. Teori yang berkaitan dengan konsep belajar di mana kebutuhan diperoleh dari budaya. Sutrisno (2013) mengemukakan motivasi adalah faktor yang mendorong seseorang untuk melakukan suatu aktivitas tertentu, motivasi sering kali diartikan pula sebagai faktor pendorong perilaku seseorang. Mangkunegara (2012) juga mengemukakan motivasi 
adalah kondisi atau energi yang menggerakkan diri karyawan yang terarah atau tertuju untuk mencapai tujuan organisasi perusahaan. Menurut Hasibuan (2011) motivasi berasal dari kata Latin movere yang berarti dorongan atau menggerakkan. Motivasi (motivation) dalam manajemen hanya ditujukan pada sumber daya manusia umumnya dan bawahan khususnya. Motivasi mempersoalkan bagaimana caranya mengarahkan daya dan potensi bawahan, agar mau bekerja sama secara produktif berhasil mencapai dan mewujudkan tujuan yang telah ditentukan. Motivasi adalah hal yang menyebabkan, menyalurkan dan mendukung perilaku manusia, supaya mau bekerja giat dan antusias mencapai hasil yang optimal.

\section{Lingkungan Kerja}

Lingkungan kerja berkaitan dengan segala sesuatu yang berada di tempat kerja. Lingkungan kerja adalah segala kondisi yang berada di sekitar karyawan yang dihubungkan dengan terjadinya perubahan psikologis dalam diri karyawan yang bersangkutan (Nitisemito. 2010). Selain itu definisi lain dikemukakan oleh Sedarmayanti (2013) yang mendefinisikan lingkungan kerja sebagai keseluruhan alat perkakas dan bahan yang dihadapi, lingkungan sekitarnya dimana seseorang bekerja, metode kerjanya, serta pengaturan kerjanya baik sebagai perseorangan maupun sebagai kelompok. Dari berbagai pendapat di atas, maka dapat disimpulkan bahwa lingkungan kerja adalah segala sesuatu yang berada di sekitar karyawan dan dapat mempengaruhi karyawan dalam menjalankan tugas-tugas yang diberikan. Lingkungan kerja dapat menambah kenyamanan dan konsentrasi karyawan sehingga mampu meningkatkan kinerja yang dimiliki. Sedangkan lingkungan kerja yang kurang nyaman bagi karyawan dan dianggap tidak memadai akan dapat menimbulkan penurunan kinerja karyawan, karyawan akan merasa tidak betah dan tidak bersemangat dalam menjalankan kewajibannya dan menyelesaikan pekerjaan-pekerjaan yang diberikan. Hal ini akan berdampak buruk bagi perusahaan.

\section{Tinjauan Penelitian Terdahulu}

Penelitian yang dilakukan oleh Qomariah (2012) dengan judul "Pengaruh Budaya Organisasi, Kepemimpinan dan Komitmen terhadap Kinerja Dosen pada Perguruan Tinggi Swasta di Kabupaten Jember", Berdasarkan hasil penelitian menunjukkan variabel budaya organisasi berpengaruh terhadap kinerja dosen, sedangkan variabel kepemimpinan dan komitmen organisasi tidak berpengaruh terhadap kinerja dosen. 
Penelitian yang dilakukan oleh Eros (2014) dengan judul "Pengaruh Motivasi dan Kedisiplinan Kerja Guru Terhadap Kinerja Guru di SMP Negeri Kecamatan Brebes Kabupaten Brebes Jawa Tengah”, Berdasarkan Hasil Penelitian ditemukan bahwa 1) ada pengaruh yang positif dan signifikan motivasi kerja guru terhadap kinerja guru. Besarnya pengaruh $61,1 \%$ 2) ada pengaruh yang positif dan signifikan kedisiplinan kerja guru terhadap kinerja guru.

Penelitian yang dilakukan oleh Nefrida (2016) dengan judul "Pengaruh Kompetensi Guru dan Lingkungan Kerja terhadap Kinerja Guru I SMK di Jambi”. Dari hasil analisis, menunjukkan bahwa 1) terdapat pengaruh kompetensi guru terhadap kinerja guru sekolah menengah kejuruan negeri I kota jambi sebesar 53,6 \%,2) terdapat pengaruh lingkungan kerja terhadap kinerja guru sekolah menengah kejuruan negeri I kota Jambi sebesar 69,6 \%, 3) terdapat pengaruh kompetensi guru dan lingkungan kerja terhadap kinerja guru sekolah menengah kejuruan negeri I kota Jambi sebesar 72,8\%.

\section{Hipotesis}

Menurut Sugiyono (2012) hipotesis diartikan sebagai jawaban sementara terhadap rumusan masalah penelitian. Penelitian harus disusun dengan metode yang sistematis yaitu melewati beberapa tahapan. Perumusan hipotesis merupakan langkah ketiga dalam penelitian setelah mengemukakan kerangka berpikir dan landasan teori. Hipotesis merupakan jawaban semetara dari permasalahan yang akan diteliti.

1. H1: Gaya kepemimpinan persuasif berpengaruh terhadap kinerja guru SMAN 1 Tanggul.

2. H2: Motivasi kerja berpengaruh terhadap kinerja guru SMAN 1 Tanggul

3. H3: Lingkungan kerja fisik berpengaruh terhadap kinerja guru SMAN 1 Tanggul.

\section{METODE PENELITIAN}

Jenis penelitian ini menggunakan metode kausalitas. Menurut Sugiyono (2012), metode kausalitas adalah suatu metode yang menjelaskan hubungan di antara kedua variabel yang bersifat sebab-akibat dan terdapat variabel yang memengaruhi dan yang dipengaruhi. Jenis penelitian ini menggunakan metode kausalitas. Menurut Sugiyono (2012), metode kausalitas adalah suatu metode yang menjelaskan hubungan di antara kedua variabel yang bersifat sebab-akibat dan terdapat variabel yang memengaruhi dan yang dipengaruhi. Sampel adalah merupakan bagian kecil dari suatu populasi. Dalam 
penelitian ini sampel yang diambil diharapkan dapat menggambarkan hasil yang sesungguhnya dari populasi (Kuncoro, 2009). Dalam penelitian ini sampel yang digunakan adalah seluruh anggota populasi yaitu 40 guru atau biasa disebut teknik sensus.

Menurut Sugiyono (2012) operasional variabel adalah suatu atribut dari sekelompok obyek yang diteliti. Dalam penelitian ini definisi operasional variabel akan dijelaskan mengenai variabel-variabel yang akan diamati sekaligus menjadi obyek pengamatan dalam penelitian.

\section{Gaya Kepemimpinan Persuasif (X1)}

Gaya kepemimpinan merupakan pola menyeluruh dari tindakan seorang pemimpin baik yang tampak maupun yang tidak tampak oleh bawahannya. Indikator yang digunakan dalam penelitian ini yaitu (Kartono, 2010):

a. Kemampuan mengambil keputusan adalah suatu pendekatan yang sistematis terhadap hakikat alternatif yang dihadapi dan mengambil tindakan.

b. Kemampuan komunikasi adalah kecakapan atau kesanggupan penyampaian pesan, gagasan, atau pikiran kepada orang lain.

c. Kemampuan mengendalikan bawahan, seorang pemimpin harus memiliki keinginan untuk membuat orang lain mengikuti keinginannya dengan menggunakan kekuatan pribadi atau kekuasaan jabatan secara efektif dan pada tempatnya.

d. Kemampuan mengendalikan emosional adalah hal yang sangat penting bagi keberhasilan hidup kita. Semakin baik kemampuan kita mengendalikan emosi semakin mudah kita akan meraih kebahagiaan.

\section{Motivasi Kerja (X2)}

Motivasi kerja adalah suatu kehendak atau keinginan yang muncul dalam diri karyawan yang menimbulkan semangat atau dorongan untuk bekerja secara optimal guna mencapai tujuan. Adapun indikatornya menurut Hasibuan (2011) adalah sebagai berikut:

a. Dorongan mencapai tujuan, adalah dorongan dalam diri karyawan untuk mengatasi segala tantangan dan hambatan dalam upaya mencapai target produksi yang dibebabkan padanya.

b. Semangat kerja, menunjukkan sejauh mana karyawan bergairah dalam melakukan tugas dan tanggung jawabnya di dalam perusahaan. 
c. Inisiatif adalah kemampuan seseorang untuk bertindak melebihi yang dibutuhkan atau yang dituntut dari pekerjaan.

d. Kreativitas adalah merupakan kemampuan untuk menciptakan sesuatu yang baru untuk memberi ide kreativ dalam memecahkan masalah atau sebagai kemampuan untuk melihat hubungan-hubungan yang baru antara unsur-unsur yang sudah ada sebelumnya.

e. Rasa tanggung jawab adalah kesadaran diri karyawan terhadap semua tingkah laku dan perbuatan yang disengaja atau pun tidak di sengaja. Tanggung jawab juga harus berasal dari dalam hati dan kemauan diri sendiri atas kewajiban yang harus di tanggung jawabkan.

\section{Lingkungan Kerja Fisik (X3)}

Lingkungan kerja fisik merupakan adalah segala sesuatu yang ada disekitar pekerja dan dapat mempengaruhi dirinya dalam menjalankan tugas-tugas yang dibebankan. Indikator dari lingkungan kerja fisik menurut Sedarmayanti (2009) yaitu:

1. Pertukaran udara, kelancaran masuk keluarnya udara dalam tempat kerja.

2. Penerangan, penerangan disini tidak terbatas pada penerangan listrik, tetapi juga termasuk penerangan matahari.

3. Intensitas kebisingan, suara yang beredar disekitar lingkungan kerja

4. Keamanan ditempat parkir, yaitu adanya petugas yang menjaga parkir.

5. Kondisi parkiran yang efektif dan memadai yaitu luas lahan parkir cukup untuk seluruh kendaraan karyawan.

\section{Kinerja Karyawan (Y)}

Kinerja karyawan adalah keseluruhan aktivitas dan prilaku karyawan dalam melaksanakan tugas, peran dan tanggung jawabnya dalam rangka memperoleh hasil kerja sesuai dengan tujuan yang telah di tetapkan. Indikator dari kinerja yaitu (Robbins dan Judge, 2013):

a. Kualitas, diukur dari persepsi karyawan terhadap kualitas pekerjaan yang dihasilkan serta kesempurnaan tugas terhadap keterampilan dan kemampuan karyawan.

b. Kuantitas, merupakan jumlah yang dihasilkan dinyatakan dalam istilah seperti jumlah unit, jumlah siklus aktivitas yang diselesaikan. 
c. Ketepatan waktu, merupakan tingkat aktivitas diselesaikan pada awal waktu yang dinyatakan, dilihat dari sudut koordinasi dengan hasil output serta memaksimalkan waktu yang tersedia untuk aktivitas lain.

d. Efektivitas, merupakan tingkat penggunaan sumber daya organisasi (tenaga, uang, teknologi, bahan baku) dimaksimalkan dengan maksud menaikkan hasil dari setiap unit dalam penggunaan sumber daya.

e. Kemandirian, merupakan tingkat seorang karyawan yang nantinya akan dapat menjalankan fungsi kerjanya

f. Komitmen kerja, merupakan suatu tingkat dimana karyawan mempunyai komitmen kerja dengan instansi dan tanggung jawab karyawan terhadap kantor.

\section{HASIL PENELITIAN}

\section{Hasil Analisis Statistik Dekskriptif}

Data diperoleh dari kuisioner yang telah disebarkan ke guru SMAN 1 Tanggul. Total kuisioner yang disebarkan adalah 40 kuisioner. Pengambilan sampel dengan menggunakan metode sensus. Dengan total kuesioner yang terisi penuh dan kembali adalah 40 kuesioner. Berdasarkan perhitungan statistik diketahui bahwa responden dengan umur termuda (Minimum) adalah 23 tahun, sedangkan responden dengan umur tertua (Maximum) adalah 60 tahun. Selisih antara nilai tertua (Maximum) dan termuda (Minimum) umur responden adalah 37 tahun. Penjumlahan (Sum) dari umur 40 responden adalah 1790 tahun. Rata-rata (Mean) dari umur responden adalah 44,75 tahun.

Berdasarkan perhitungan statistik dapat diketahui bahwa responden yang berjenis kelamin perempuan lebih banyak dari pada laki-laki. Guru yang berjenis kelamin perempuan berjumlah 21 (52\%) lebih banyak dari responden laki-laki yang berjumlah $19(48 \%)$.

\section{Analisis Regresi Linier Berganda}

Model persamaan regresi yang baik adalah yang memenuhi persyaratan asumsi klasik, antara lain semua data berdistribusi normal, model harus bebas dari gejala multikolinearitas dan terbebas dari heterokedastisitas. Dari analisis sebelumnya telah terbukti bahwa model persamaan yang diajukan dalam penelitian ini telah memenuhi persyaratan asumsi klasik sehingga model persamaan dalam penelitian ini sudah dianggap baik. Analisis regresi digunakan untuk menguji hipotesis tentang pengaruh 
secara parsial variabel bebas terhadap variabel terikat. Berdasarkan estimasi regresi linier berganda dengan program SPSS versi 22,0 diperoleh hasil sebagai berikut:

Tabel 4. Hasil Analisis Regresi Linier Berganda

\begin{tabular}{cccc}
\hline No & Variabel & Koefisien Regresi & Signifikansi \\
\hline $\mathbf{1}$ & Konstanta & 3,294 & 0,019 \\
\hline $\mathbf{2}$ & Gaya Kepemimpinan $\left(\mathrm{X}_{1}\right)$ & 0,328 & 0,005 \\
\hline $\mathbf{3}$ & Motivasi Guru $\left(\mathrm{X}_{2}\right)$ & 0,455 & 0,001 \\
\hline $\mathbf{4}$ & Lingkungan Kerja Fisik $\left(\mathrm{X}_{3}\right)$ & 0,366 & 0,005 \\
\hline
\end{tabular}

Sumber: Data Diolah.

Berdasarkan tabel 4, dapat diketahui persamaan regresi yang terbentuk adalah:

$$
Y=3,294+0,328 X_{1}+0,455 X_{2}+0,366 X_{3}
$$

Dari persamaan tersebut dapat diartikan bahwa:

a. Konstanta $=3,294$ menunjukkan besaran kinerja guru 3,294 satuan pada saat gaya kepemimpinan, motivasi guru, dan lingkungan kerja fisik sama dengan nol.

b. $\beta_{1}=0,328$ artinya meningkatnya gaya kepemimpinan per satu satuan akan meningkatkan kinerja guru sebesar 0,328 satuan apabila motivasi guru, dan lingkungan kerja fisik sama dengan nol. Hal ini juga mengindikasikan bahwa gaya kepemimpinan berpengaruh positif terhadap kinerja guru yang berarti semakin baik gaya kepemimpinan akan berdampak pada semakin baik pula kinerja guru dengan asumsi motivasi guru, dan lingkungan kerja fisik konstan.

c. $\beta_{2}=0,455$ artinya meningkatnya motivasi guru per satu satuan akan meningkatkan kinerja guru sebesar 0,455 satuan apabila gaya kepemimpinan, dan lingkungan kerja fisik sama dengan nol. Hal ini juga mengindikasikan bahwa motivasi guru berpengaruh positif terhadap kinerja guru yang berarti semakin baik motivasi guru akan berdampak pada semakin ringginya kinerja guru dengan asumsi gaya kepemimpinan, dan lingkungan kerja fisik konstan.

d. $\beta_{3}=0,366$ artinya meningkatnya lingkungan kerja fisik per satu satuan akan meningkatkan kinerja guru sebesar 0,366 satuan apabila gaya kepemimpinan, dan motivasi guru sama dengan nol. Hal ini juga mengindikasikan bahwa lingkungan kerja fisik berpengaruh positif terhadap kinerja guru yang berarti semakin tinggi lingkungan kerja fisik akan berdampak pada meningkatnya kinerja guru dengan asumsi gaya kepemimpinan, dan motivasi guru konstan.

\section{Uji Hipotesis}


Hipotesis dalam penelitian ini diuji kebenarannya dengan menggunakan uji parsial. Pengujian dilakukan dengan melihat statistik $\mathrm{t}$ hitung dengan nilai statistik $\mathrm{t}$ tabel dan taraf signifikansi ( $p$-value), jika taraf signifikansi yang dihasilkan dari perhitungan di bawah 0,05 maka hipotesis diterima, sebaliknya jika taraf signifikansi hasil hitung lebih besar dari 0,05 maka hipotesis ditolak. Nilai $t_{\text {tabel }}$ didapatkan dari df $=\mathrm{n}-\mathrm{k}$ (40-4) sama dengan 36. Dimana n adalah jumlah sampel dan k adalah jumlah variabel penelitian. Jadi untuk melihat $\mathrm{t}_{\text {tabel }}$ caranya dengan melihat tabel $\mathrm{t}$ baris ke 36 yaitu 1,6883.

Hasil perhitungan menunjukkan perbandingan antara taraf signifikansi dengan signifikansi tabel adalah sebagai berikut:

1. Hasil uji gaya kepemimpinan mempunyai nilai signifikansi hitung sebesar 0,005 dan lebih kecil dari 0,05 dan $\mathrm{t}$ hitung $(2,981)>\mathrm{t}$ tabel $(1,6883)$ yang berarti bahwa hipotesis gaya kepemimpinan mempunyai pengaruh terhadap kinerja guru diterima. Hal ini juga menunjukkan bahwa gaya kepemimpinan mempengaruhi kinerja guru yang berarti semakin baik gaya kepemimpinan akan berdampak pada semakin tinggi kinerja guru.

2. Hasil uji motivasi guru mempunyai nilai signifikansi sebesar 0,001 dan lebih kecil dari 0,05 dan $\mathrm{t}$ hitung $(3,635)>\mathrm{t}$ tabel $(1,6883)$ yang berarti bahwa hipotesis motivasi guru mempunyai pengaruh terhadap kinerja guru diterima. Hal ini juga menunjukkan bahwa motivasi guru mempengaruhi kinerja guru yang berarti semakin baik motivasi guru akan berdampak pada semakin tinggi kinerja guru.

3. Hasil uji lingkungan kerja fisik mempunyai nilai signifikansi sebesar 0,005 dan lebih kecil dari 0,05 dan $\mathrm{t}$ hitung $(2,984)>\mathrm{t}$ tabel $(1,6883)$ yang berarti bahwa hipotesis lingkungan kerja fisik mempunyai pengaruh terhadap kinerja guru diterima. Hal ini juga menunjukkan bahwa lingkungan kerja fisik mempengaruhi kinerja guru yang berarti semakin baik lingkungan kerja fisik akan berdampak pada semakin tinggi kinerja guru.

\section{Pembahasan}

Secara nyata berdasarkan hasil penelitian menunjukan bahwa secara statistik kedua hipotesis yang diajukan mendukung teori dan hipotesis yang diajukan. Berdasarkan hasil pengujian secara statistik, penjelasan dari masing-masing pengaruh variabel dijelaskan sebagai berikut:

\section{Pengaruh Gaya Kepemimpinan Terhadap Kinerja Guru.}


Melalui hasil perhitungan yang telah dilakukan diperoleh taraf signifikansi sebesar 0,005 dan lebih kecil dari 0,05 dan $t$ hitung $(2,981)>t$ tabel $(1,6883)$ yang berarti hipotesis yang menyatakan gaya kepemimpinan berpengaruh positif dan signifikan terhadap kinerja guru diterima. Pengujian secara statistik ini membuktikan bahwa ada pengaruh positif dan signifikan gaya kepemimpinan terhadap kinerja guru. Artinya bahwa gaya kepemimpinan yang meliputi Kepala sekolah selalu siap untuk mengambil keputusan dalam penerapan sebuah kebijakan, Kepala sekolah berkomunikasi dengan guru-guru dengan efektif, Kepala sekolah mempunyai jiwa kepemimpinan yang baik dan Kepala sekolah selalu bersikap tenang dan tegas kepada bawahannya berpengaruh terhadap kinerja guru.

Menurut Robbins dan Judge (2013) gaya kepemimpinan mempunyai peran yang penting dalam mempengaruhi cara kerja karyawan. Perilaku kepemimpinan dapat memberikan dampak positif ataupun negatif terhadap kinerja karyawan yang dipimpinnya. Kepemimpinan merupakan kekuatan aspirasional, kekuatan semangat, dan kekuatan moral yang kreatif, yang mampu mempengaruhi para anggota untuk mengubah sikap, sehingga mereka bisa satu pemikiran dengan keinginan pemimpin. Seorang pemimpin sebaiknya mampu memahami karakter karyawan. Hasil ini berbeda dengan hasil penelitian Qomariah (2012) yang menemukan bahwa kepemimpinan tidak berpengaruh terhadap kinerja. Adapun penelitian sebelumnya yang sesuai adalah Baihaqi (2015) dan Lumbanraja (2014) yang menyatakan ada pengaruh gaya kepemimpinan terhadap kinerja guru dan sesuai dengan hipotesis yang diajukan, yaitu gaya kepemimpinan berpengaruh terhadap kinerja guru.

\section{Pengaruh Motivasi Guru Terhadap Kinerja Guru}

Melalui hasil perhitungan yang telah dilakukan diperoleh taraf signifikansi sebesar 0,001 dan lebih kecil dari 0,05 dan $\mathrm{t}$ hitung $(3,635)>\mathrm{t}$ tabel $(1,6883)$ yang berarti hipotesis yang menyatakan motivasi guru berpengaruh positif dan signifikan terhadap kinerja guru diterima. Pengujian secara statistik ini membuktikan bahwa ada pengaruh positif dan signifikan motivasi guru terhadap kinerja guru. Artinya bahwa motivasi guru yang meliputi termasuk guru dengan produktivitas yang tinggi, selalu bersemangat ketika bekerja, mempunyai inisiatif ketika kesulitan dalam bekerja, pekerjaan membutuhkan kreatifitas yang tinggi dan bertanggung jawab akan pekerjaan untuk mencapai target kerja, berpengaruh terhadap kinerja guru. 
Menurut Sutrisno (2013) motivasi adalah faktor yang mendorong seseorang untuk melakukan suatu aktivitas tertentu, motivasi sering kali diartikan pula sebagai faktor pendorong perilaku seseorang. Motivasi (motivation) dalam manajemen hanya ditujukan pada sumber daya manusia umumnya dan bawahan khususnya. Motivasi mempersoalkan bagaimana caranya mengarahkan daya dan potensi bawahan, agar mau bekerja sama secara produktif berhasil mencapai dan mewujudkan tujuan yang telah ditentukan. Kinerja karyawan adalah hasil kerja secara kualitas dan kuantitas yang dicapai oleh seorang pegawai dalam melaksanakan tugasnya sesuai dengan tanggung jawab yang diberikan kepadanya. Standar pekerjaan dapat ditentukan dari isi suatu pekerjaan, dapat dijadikan sebagai dasar penilaian setiap pekerjaan (Bangun, 2012). Hasil ini mendukung penelitian sebelumnya oleh Eros (2014), Baihaqi (2015), Lumbanraja (2014), Prihanto (2017) dan Ardiana (2017) yang menyatakan ada pengaruh Motivasi Guru terhadap Kinerja Guru dan sesuai dengan hipotesis yang diajukan, yaitu Motivasi Guru berpengaruh terhadap Kinerja Guru.

\section{Pengaruh Lingkungan Kerja Fisik Terhadap Kinerja Guru}

Melalui hasil perhitungan yang telah dilakukan diperoleh taraf signifikansi sebesar 0,005 dan lebih kecil dari 0,05 dan $\mathrm{t}$ hitung $(2,984)>\mathrm{t}$ tabel $(1,6883)$ yang berarti hipotesis yang menyatakan lingkungan kerja fisik berpengaruh positif dan signifikan terhadap kinerja guru diterima. Pengujian secara statistik ini membuktikan bahwa ada pengaruh positif dan signifikan lingkungan kerja fisik terhadap kinerja guru. Artinya bahwa lingkungan kerja fisik yang meliputi dapat bernafas dengan lancer karena saluran udara di tempat kerja baik, membutuhkan penerangan yang baik ketika bekerja agar hasil kerja baik pula, bekerja dengan tenang karena tempat kerja jauh dari kebisingan lalu lintas, tenang karena keamanan kendaraan di tempat kerja sudah terjamin dan mudah untuk memarkir kendaraan karena lahan parkir untuk guru luas, berpengaruh terhadap kinerja guru.

Hubungan antara lingkungan kerja fisik dan kinerja karyawan diungkapkan pula oleh Sedarmayanti (2009) yang menyatakan bahwa manusia akan mampu melaksanakan kegiatannya dengan baik, sehingga dicapai suatu hasil yang optimal, apabila diantaranya ditunjang oleh kondisi lingkungan yang sesuai. Kenyamanan tempat kerja baik secara fisik dan non fisik merupakan harapan bagi setiap karyawan. Karyawan selalu menuntut adanya lingkungan kerja yang nyaman, sehingga optimalisasi kerja karyawan dapat tercapai dengan baik. Karyawan tidak akan bekerja secara optimal apabila kondisi 
lingkungan tempat bekerja tidak baik seperti penerangan tidak terpenuhi, suara gaduh dan suhu udara yang lembab dan panas. Hasil ini mendukung penelitian sebelumnya oleh Nefrida (2016) dan Prihanto (2017), yang menyatakan ada pengaruh lingkungan kerja fisik terhadap kinerja guru dan sesuai dengan hipotesis yang diajukan, yaitu lingkungan kerja fisik berpengaruh terhadap kinerja guru.

\section{KESIMPULAN}

Berdasarkan analisis data dan pembahasan yang telah diuraikan, maka dapat ditarik kesimpulan sebagai berikut:

1. Gaya Kepemimpinan berpengaruh positif dan signifikan terhadap kinerja guru. Hasil temuan ini berarti semakin baik gaya kepemimpinan maka akan meningkatkan kinerja guru

2. Motivasi guru berpengaruh positif dan signifikan terhadap kinerja guru. Hasil temuan ini berarti semakin baik motivasi guru maka akan meningkatkan kinerja guru

3. Lingkungan kerja fisik berpengaruh positif dan signifikan terhadap kinerja guru. Hasil temuan ini berarti semakin baik lingkungan kerja fisik maka akan meningkatkan kinerja guru.

\section{DAFTAR PUSTAKA}

Ardiana, Titin Eka. 2017. Pengaruh Motivasi Kerja Guru Terhadap Kinerja Guru Akuntansi SMK di Kota Madiun. Jurnal Akuntansi dan Pajak, Vol. 17, No. 02, Januari 2017 ISSN : 1412-629x

Azhad, Muhammad Naely: Anwar dan Nurul Qomariah. 2015. Manajemen Sumber Daya Manusia. Jember: Cahaya Ilmu.

Baihaqi, Muhammad Iqbal. 2015. Pengaruh Gaya Kepemimpinan Kepala Sekolah dan Motivasi Kerja terhadap Kinerja Guru di MA Ma'arif Selorejo Blitar. KONSTRUKTIVISME, Vol. 7, No. 2, Juli 2015 P-ISSN: 1979-9438, E-ISSN: 24452355

Bangun, Wilson. 2012. Manajemen Sumber Daya Manusia. Jakarta: Erlangga.

Barnawi dan Arifin, Muhammad. 2014. Kinerja Guru Profesional. Yogyakarta: ArRuzz. Media.

Bohlander, George., and Snell, Scott. 2010. Principles of Human Resource. Management, 15 th ed. Mason, $\mathrm{OH}$ : South Western - Cengage Learning 
Chandrasekar. 2011. Workplace Environment and Its Impact on Organisational Performance in Public Sector Organisations. Internasional Journal of Enterprise Computing and Business Systems (Online) Vol. 1 Issue 1 January 2011

Departemen Pendidikan Nasional, 2003. Undang-Undang Nomor 20 Tahun 2003, Tentang Sistem Pendidikan Nasional, Jakarta: Depdiknas.

Departemen Pendidikan Nasional. 2007. Undang-undang SISDIKNAS (Sistem pendidikan Nasional) UU RI No. 20 tahun 2003 dan undang-undang Guru dan dosen UU RI Nomor 14 tahun 2005. Jakarta.

Depdiknas. 2010. Panduan Pendidikan Karakter di SMP. Jakarta: Balitbang Depdiknas.

Dessler, Gary. 2015. Manajemen Sumber Daya Manusia. Jakarta: Salemba Empat.

Direktorat Jenderal Peningkatan Mutu Pendidik dan Tenaga Kependidikan dan. Jenderal Pendidikan Tinggi. 2010. Prosedur Operasional Standar. Penyelenggaraan KKG dan MGMP, Jakarta: Kementerian Pendidikan.

Ernawati dan Ambarini. 2010. Pengaruh Hubungan Kerja dan Lingkungan Kerja Terhadap Kinerja Pegawai dengan Motivasi Kerja sebagai Variabel Moderating. Jurnal ekonomi dan kewirausahaan 10 (2): 109-118. 